\title{
Author Correction: Lipidomic Signatures of Nonhuman Primates with Radiation-Induced Hematopoietic Syndrome
}

\author{
Evan L. Pannkuk ${ }^{1}$, Evagelia C. Laiakis ${ }^{2}$, Vijay K. Singh ${ }^{3,4}$ \& Albert J. Fornace ${ }^{2,5}$
}

Correction to: Scientific Reports https://doi.org/10.1038/s41598-017-10299-w, published online 29 August 2017

The original version of this Article contained an error in the Abstract.

"The current study addresses temporal changes in the serum lipidome from $4 \mathrm{~h}$ to $28 \mathrm{~d}$ in nonhuman primates (NHPs) with radiation-induced hematopoietic syndrome (6.5 Gy exposure, $\left.\mathrm{LD}_{50 / 30}\right)$."

now reads:

"The current study addresses temporal changes in the serum lipidome from $4 \mathrm{~h}$ to $28 \mathrm{~d}$ in nonhuman primates (NHPs) with radiation-induced hematopoietic syndrome (6.5 Gy exposure, $\left.\mathrm{LD}_{50 / 60}\right)$."

This error has now been corrected in the PDF and HTML versions of the Article.

(i) Open Access This article is licensed under a Creative Commons Attribution 4.0 International License, which permits use, sharing, adaptation, distribution and reproduction in any medium or format, as long as you give appropriate credit to the original author(s) and the source, provide a link to the Creative Commons license, and indicate if changes were made. The images or other third party material in this article are included in the article's Creative Commons license, unless indicated otherwise in a credit line to the material. If material is not included in the article's Creative Commons license and your intended use is not permitted by statutory regulation or exceeds the permitted use, you will need to obtain permission directly from the copyright holder. To view a copy of this license, visit http://creativecommons.org/licenses/by/4.0/.

(c) The Author(s) 2019

\footnotetext{
${ }^{1}$ Tumor Biology Program, Lombardi Comprehensive Cancer Center, Georgetown University, Washington, D.C., 20057, USA. '2 Department of Biochemistry and Molecular \& Cellular Biology, Georgetown University Medical Center, Washington, D.C., 20057, USA. ${ }^{3}$ Department of Pharmacology and MolecularTherapeutics, F. Edward Hébert School of Medicine, Bethesda, USA. ${ }^{4}$ Armed Forces Radiobiology Research Institute, Uniformed Services University of the Health Sciences, Bethesda, MD, 20814, USA. ${ }^{5}$ Deparment of Oncology Georgetown University, Washington, D.C., 20057, USA. Correspondence and requests for materials should be addressed to A.J.F. (email: af294@georgetown. edu)
} 